\title{
OVARIAN FUNCTION AND PROGESTIN CONTENT IN RESPONSE TO GONADOTROPHINS
}

\author{
G. J. MACDONALD \\ Endocrinology Research Laboratories, Harvard School of Dental Medicine, \\ Boston, Massachusetts
}

(Received 21st June 1968)

\begin{abstract}
Summary. Luteinizing hormone was administered to rats hypophysectomized on the morning of pro-oestrus or metoestrus after a 7-day rest. The following changes were noted: vaginal smears contained cornified epithelial cells; ovarian weights were unchanged compared to those of controls; uterine weights increased, and the lumina contained fluid. These observations indicate that $\mathrm{LH}$ induces oestrogen secretion. Analyses of the sterol and steroid content of the ovaries showed trends without statistical significance. Prolactin was administered immediately after hypophysectomy in similar animals and the following changes were noted: vaginal smears contained leucocytes; vaginal epithelia were bilaminar; ovarian weights decreased in rats operated on during prooestrus and remained the same in rats operated on during metoestrus when compared to those of hypophysectomized controls; and uterine weights were not different from those of hypophysectomized controls. The amount of esterified cholesterol increased in animals which were operated on during pro-oestrus but not during metoestrus. In contrast, when prolactin and L.r were administered, the vaginal smear still contained leucocytes but the vaginal epithelia were stratified and mucified; ovarian weights increased in animals operated on during metoestrus, but not during pro-oestrus, and uterine weights increased in animals operated on during pro-oestrus. LH reduced the esterified cholesterol in the ovaries of rats operated on during pro-oestrus. The amounts of progesterone and 20x-hydroxy-pregn-4-en-3-one were greater in rats operated on during metoestrus and LH treatment tended to increase the content of these steroids. The data suggest the ovaries of animals operated on during pro-oestrus which contain older corpora lutea are capable of secreting progesterone as well as oestrogen.
\end{abstract}

\section{INTRODUGTION}

Ovaries of hypophysectomized rats possessing naturally formed corpora lutea (CL) have the capacity to secrete oestrogen when stimulated with luteinizing hormone (Macdonald, Armstrong \& Greep, 1966). Oestrogen secretion can also be induced by $\mathrm{LH}$ while progesterone secretion is maintained with pituitary autografts (Macdonald, Armstrong \& Greep, 1967). During the course of these 
studies it was noted that GL of rats hypophysectomized on the morning of pro-oestrus were also able to secrete some progesterone when stimulated with exogenous LH. The following study was initiated in an attempt to determine whether CL at pro-oestrus are able to secrete progesterone in response to prolactin replacement.

\section{MATERIALS AND METHODS}

All rats used were obtained from the Holtzman Company at 55 days of age. They were housed in a light, temperature- and humidity-controlled room. Food and water were supplied freely. Vaginal smears were taken daily. Animals were hypophysectomized by the parapharyngeal approach on the day of prooestrus or metoestrus. When anterior pituitaries were autotransplanted, they were held in physiological saline until the kidney was exposed, the capsule slit, and a pocket formed. They were then slid under the capsule towards the caudal pole.

Prolactin (NIH-P-s7) was administered twice daily in $0.2 \mathrm{ml}(12.5 \mathrm{i} . \mathrm{u} . / \mathrm{ml}$ of sterile $0.9 \% \mathrm{NaCl}$ ) beginning immediately after hypophysectomy to ensure maximal luteal maintenance. Luteinizing hormone (NIH-LH) was administered once daily in $0.2 \mathrm{ml}(250 \mu \mathrm{g} / \mathrm{ml}$ of sesame oil plus $5 \%$ beeswax $)$. Hormones were administered by subcutaneous injection. All experiments were terminated 12 days after operation. At autopsy, ovarian and uterine weights were recorded and vaginal specimens were fixed in Bouin's fluid for histological examination. The ovaries were frozen in vials on dry ice and stored in a deep freeze until extracted and analysed according to the procedure of Armstrong, O'Brien \& Greep (1964).

After thawing and grinding the tissue in $3 \mathrm{ml}$ of saline, the following tracers were added to estimate the losses due to analytical procedures: $\left[7-{ }^{3} \mathrm{H}\right]$ cholesterol palmitate; $\left[7-{ }^{3} \mathrm{H}\right]$ progesterone; $\left[7-{ }^{3} \mathrm{H}\right]$ cholesterol and $\left[{ }^{14} \mathrm{C}\right] 20 \alpha$-hydroxypregn-4-en-3-one. Each tracer had been chromatographed to free it from contaminants. The homogenates were extracted with ether and chromatography was carried out using silica gel as described by Armstrong et al. (1964).

To identify the esterified cholesterol after the first chromatography, the silica gel plates were sprayed with rhodamine and the spot removed from the plate. Following chromatography in the second dimension, progesterone and $20 \alpha$-hydroxy-pregn-4-en-3-one $(20 \alpha$-ol $)$ were identified under ultra-violet light. If too little was present for visual identification, areas of silica gel were removed correspondent to standards run in parallel. Free cholesterol was identified by rhodamine spray and isolated.

Progesterone was eluted from the silica gel with ethyl acetate, dried and reduced with 20 $\beta$-hydroxysteroid dehydrogenase (Sigma Co.) (Henning \& Zander, 1962) to $20 \beta$-hydroxy-pregn-4-en-3-one. The samples were run again in methylene chloride : ethyl ether $(5: 2)$, the reduced product identified as before, and eluted from the silica gel. All samples were analysed by the fluorescent technique of Heap (1964) with some modification. The dried eluate was partitioned between cyclohexane and water. A portion of the cyclohexane was removed to measure the recoverable radio-activity. A second portion was dried 
under a stream of nitrogen and heated with $5 \mathrm{ml} \mathrm{H}_{2} \mathrm{SO}_{4}: 80 \%$ ethanol $(2: 1)$ at $60^{\circ} \mathrm{C}$ for 3 to $6 \mathrm{~min}$. Following cooling to room temperature the amount of chromogen was measured by its fluorescence with a Turner fluorometer. The excitation wave length was $436 \mathrm{~m} \mu$ and the emission was measured at $520 \mathrm{~m} \mu$.

The 20 $\alpha$-ol was eluted from the silica gel with ethyl acetate and dried under nitrogen. It was then acetylated with $0.2 \mathrm{ml}$ acetic anhydride and $0.1 \mathrm{ml}$ pyridine for $2 \mathrm{hr}$ at room temperature. Standards of pure 20 $\alpha$-ol were acetylated similarly. Chromatography of the samples and standards was carried out again in isopropyl ether : ethyl acetate (5:2), eluted with ethyl acetate, dried and partitioned between cyclohexane and water $(1: 1)$. Subsequent procedures were the same as for progesterone analyses by the Turner fluorometer.

Both the free and the esterified cholesterols were analysed by a modification of the Leiberman-Burchard reaction. The sterols were eluted from the silica gel with $5 \mathrm{ml}$ of chloroform: methanol (2:1). The eluate was divided into two portions, one to estimate recovery by measuring radio-activity and the other to measure the quantity of the particular sterol. The latter was dried under nitrogen, eluted with $0.5 \mathrm{ml}$ chloroform and subsequently $1 \mathrm{ml}$ of acetic anhydride (acetic anhydride $: \mathrm{H}_{2} \mathrm{SO}_{4}, 25: 1$ ). Seventeen minutes later the absorbance was measured at $620 \mathrm{~m} \mu$ in a 1 - $\mathrm{ml}$ cuvette with a Cary spectrophotometer.

The data were statistically evaluated by analyses of variance and the DuncanBonner multiple range test.

\section{Experiment 1}

\section{RESULTS}

The rats used in this experiment were hypophysectomized (APX) or hypophysectomized with subsequent autograft of the pituitary (APX-tr) on the morning of pro-oestrus and were treated as described in Text-fig. 1. At autopsy on Day 12 all rats but one had evident cL. Ovaries of APX rats were larger than those of untreated APX-tr rats $(P<0.01)$ and those of APX-tr rats treated with LH were heavier still. Uteri of APX-tr rats were heavier than those of APX rats $(P<0.01)$. LH increased the uterine weights of APX-tr rats (Table 1). The LH treatment caused stratification and mucification of the vaginal epithelia and, although uterine weights increased, the uteri contained no fluid.

Ovaries from four or five rats were pooled and analysed for steroid content (Table 2). Free cholesterol was unchanged by pituitary transplantation, and reduced by $\mathbf{L H}$ treatment $(P<0.01)$. The esterified cholesterol content of ovaries from APX rats was increased due to pituitary transplantation and this sterol was reduced by administration of LH to APX-tr rats $(P<0.01)$. The progesterone content of the ovaries of the three groups was not statistically different. The $20 \alpha$-ol values obtained from ovaries of APX-tr rats were greater than those of APX rats $(P<0.01)$ and $\mathrm{LH}$ treatment reduced the content $(P<0 \cdot 05)$.

\section{Experiment 2}

The animals in this experiment were hypophysectomized on either the day of pro-oestrus or metoestrus and assigned to groups on a random basis. There were 
four treatment groups. Animals were treated as described in Text-fig. 1. Leucocytes were present in daily vaginal smears from all animals except those which received LH alone. The smears of all rats receiving LH contained only

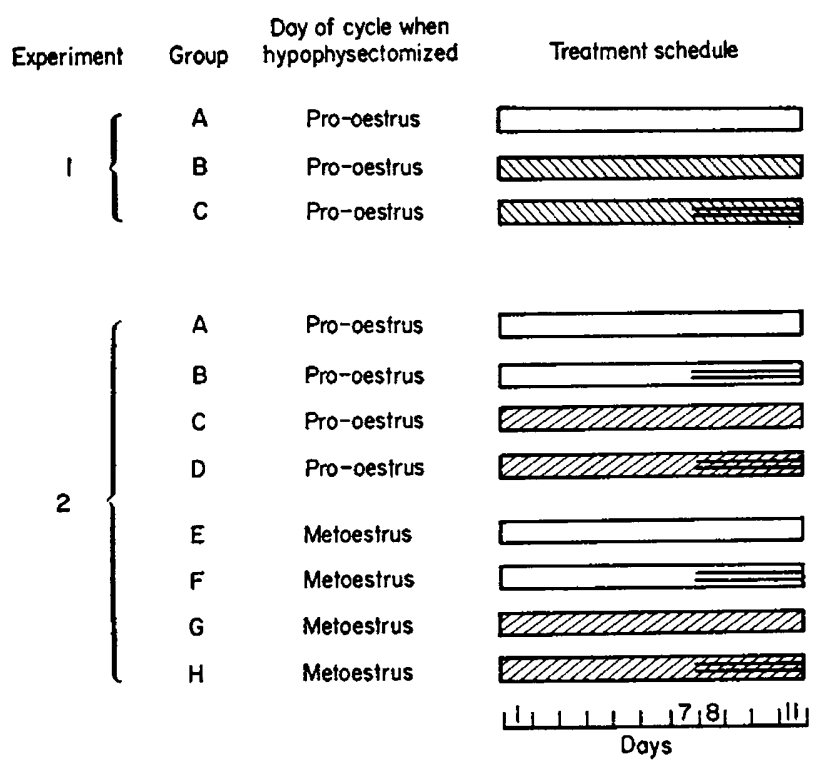

No treatment

WIT With pitory autografts

DIH $-\mathrm{LH} \rightarrow 3$ or $34,50 \mu \mathrm{g}$ in $0.2 \mathrm{ml}$ sesame oil plus $5 \%$ beeswax, daily

Q7H-p-97, 2.5 i.u. in $0.2 \mathrm{ml}$ soline, twice daily

TExT-FIG. 1. Design of experiments. Rats hypophysectomized on Day 1 and killed on Day 12.

TABLE 1

HYPOPHYSECTOMIZED RATS (APX) AND HYPOPHYSECTOMIZED RATS WITH PITUITARY AUTOGRAFTS (APX-TR)* TREATED WITH LUTEINIZING HORMONE† (NIH-LH-B3)

\begin{tabular}{|c|c|c|c|}
\hline Group & $\begin{array}{c}L H \\
50 \mu g / d a y \\
\text { Days } 8 \text { to } 11\end{array}$ & $\begin{array}{l}\text { Ovarian wt } \\
\quad(\mathrm{mg})\end{array}$ & $\begin{array}{l}\text { Lterine wt } \\
\quad(m g)\end{array}$ \\
\hline $\begin{array}{l}\text { APX (12 days) } \\
\text { APX-tr (12 days) } \\
\text { APX-tr (12 days) }\end{array}$ & $\begin{array}{l}0 \\
0 \\
+\end{array}$ & $\begin{array}{ll}43 \cdot 7 \pm 1 \cdot 2 \ddagger & (14) \\
35 \cdot 4 \pm 1 \cdot 0 & (15) \\
43 \cdot 5 \pm 2 \cdot 4 & (15)\end{array}$ & $\begin{array}{ll}136 \pm 3 \cdot 7 & (14) \\
210 \pm 13 \cdot 4 & (15) \\
272 \pm 23 \cdot 3 & (15)\end{array}$ \\
\hline
\end{tabular}

Ovarian weights: APX versus APX-tr rats $(P<0 \cdot 05)$. LH versus no LH treatment $(P<0.01)$.

Uterine weights: APX versus APX-tr rats $(P<0 \cdot 01)$. LH versus no $\mathrm{LH}$ treatment $(P<0.01)$.

* Rats, 70 to 77 days of age.

$\dagger$ Injected in $0.2 \mathrm{ml}$ sesame oil $+5 \%$ beeswax, subcutaneously.

$\ddagger$ Mean \pm S.E.

cornified epithelial cells by Day 12, the 4th day after the initial LH injection (Table 3). Histological sections of the vaginae confirmed this observation. Uterine fluid was present in eight of the ten rats hypophysectomized in pro- 
oestrus and seven of the nine hypophysectomized in metoestrus. This attests to the ability of the luteinized ovary to secrete oestrogen. The vaginal epithelium responded in a consistent manner to the gonadotrophins, independent of the day of the hypophysectomy (Plate 1). Vaginal smears of those rats treated with prolactin and then LH did not contain cornified epithelial cells and by histology the animals were found to have a stratified and mucified vaginal epithelium. This was considered to be a positive sign of continuing progesterone secretion in the presence of oestrogen secreted in response to LH. There was no difference between the ovarian weights of untreated animals operated on during prooestrus or metoestrus and those given LH alone. The ovaries of rats operated

TABLE 2

EFFECT OF PITUITARY TRANSPLANTATION AND LH ON THE STEROL AND STEROID GONTENT OF OVARIES FROM RATS HYPOPHYSECTOMIZED IN PRO-OESTRUS

\begin{tabular}{|c|c|c|c|c|c|}
\hline \multirow{2}{*}{$\frac{R e f . c o d e}{\mathrm{~A}}$} & Treatment & \multicolumn{2}{|c|}{$\begin{array}{l}\text { Cholesterol ( } \mu g / m g \text { ovary }) \\
\text { Free }\end{array}$} & \multicolumn{2}{|c|}{$\begin{array}{l}\text { Progestins }(\mu g / 100 \mathrm{mg} \text { ovary }) \\
\text { Progesterone } 20 \alpha-o l\end{array}$} \\
\hline & Hypophysectomized & $3.97 \pm 0.05 *$ & $11 \cdot 35 \pm 0.38$ & $2 \cdot 93 \pm 0.90$ & $0.52 \pm 0.04$ \\
\hline B & $\begin{array}{l}\text { Hypophysectomized } \\
\text { with pituitary auto- } \\
\text { transplants }\end{array}$ & $4 \cdot 00 \pm 0.01$ & $14 \cdot 24 \pm 0 \cdot 17$ & $4 \cdot 14 \pm 0 \cdot 79$ & $1 \cdot 59 \pm 0 \cdot 17$ \\
\hline G & $\begin{array}{l}\text { Hypophysectomized } \\
\text { with pituitary auto- } \\
\text { transplants given } 50 \\
\mu \mathrm{g} \text { LH daily Days } 8 \text { to } \\
1 \mathrm{I} \dagger\end{array}$ & $3 \cdot 43 \pm 0 \cdot 01$ & $7 \cdot 00 \pm 0 \cdot 68$ & $5 \cdot 08 \pm 0 \cdot 68$ & $1 \cdot 16 \pm 0.03$ \\
\hline
\end{tabular}

Cholesterol, free: A versus B,C; B versus $\mathrm{C}(P<0.01)$.

Cholesterol, esterified: B versus $\mathrm{C}(P<0.01)$.

Progesterone: no significant difference.

20 $\alpha$-ol: A versus B,C $(P<0 \cdot 01)$.

B versus $\mathrm{C}(P<0.05)$.

* Mean \pm S.E. represents three determinations based on analyses of ovaries from four or five rats. $\dagger$ NIH-LH-B $3,50 \mu \mathrm{g}$ in $0.2 \mathrm{ml}$ sesame oil $+5 \%$ beeswax injected daily, subcutaneously.

on during pro-oestrus and treated with prolactin were smaller than those of untreated controls $(P<0.01)$. In animals operated on during metoestrus, this effect was not evident. Combining LH and prolactin treatment increased the ovarian weights significantly but only in animals operated on during metoestrus.

The ovaries from two or three rats were pooled and analysed for free or esterified cholesterol content (Table 4). No significant changes were noted in free cholesterol. The esterified cholesterol content of the ovaries of rats operated on during pro-oestrus was significantly reduced $(P<0.05)$ by LH but not by prolactin.

The progesterone content of all ovaries from animals operated on during metoestrus was greater than that of all animals operated on during pro-oestrus $(P<0 \cdot 01)$. The values for untreated animals were not statistically different. Treatment with LH alone reduced the progesterone content in both groups, the effect approached significance at the $5 \%$ level in animals operated on during pro-oestrus. The progesterone content of ovaries from rats treated with prolactin alone or with LH was not statistically different. 
The amount of $20 x$-ol found in the ovaries of all rats hypophysectomized during pro-oestrus, was statistically different from rats hypophysectomized in metoestrus $(P<0.01)$. The mean content $(\mu \mathrm{g} / 100 \mathrm{mg})$ was depressed by $\mathrm{LH}$ alone and increased by LH administered in addition to prolactin. The effect of LH alone in rats hypophysectomized during metoestrus was nil. However, prolactin increased the mean content of this steroid $(P<0.01)$ and additional LH increased the mean content further although it was not statistically significant. In animals treated with prolactin or prolactin plus $\mathbf{L H}$, there was a statistically greater amount of $20 \alpha$-ol in the ovaries when the preceding hypophysectomy was carried out during metoestrus rather than pro-oestrus.

TABLE 3

EFFEGT OF LH* AND/OR PROLAGTIN† IN HYPOPHYSEGTOMIZED RATS 65 TO 78 DAYS OF AGE

\begin{tabular}{|c|c|c|c|c|c|c|}
\hline Ref. code & $\begin{array}{l}\text { Stage of cycle } \\
\text { when operated }\end{array}$ & No. rats & Treatment (Days) & $\begin{array}{l}\text { Ovarian wt } \\
\quad(m g)\end{array}$ & $\begin{array}{l}\text { Uterine wt } \\
\quad(m g)\end{array}$ & $\begin{array}{l}\text { Cells present in } \\
\text { vaginal smears }\end{array}$ \\
\hline A & Pro-oestrus & 11 & None (1 to 11 ) & $38 \pm 2 \cdot 0 \ddagger$ & $126 \pm 9$ & Leucocytes \\
\hline B & Pro-oestrus & 10 & $\begin{array}{l}\text { None (1 to } 7) \\
\text { LH }(8 \text { to } 11)\end{array}$ & $40 \pm 2 \cdot 0$ & $251 \pm 13$ & $\begin{array}{l}\text { Cornified } \\
\text { epithelial cells }\end{array}$ \\
\hline C. & Pro-oestrus & 9 & Prolactin (1 to 11$)$ & $27 \pm 1 \cdot 2$ & $119 \pm 16$ & Leucocytes \\
\hline $\mathbf{D}$ & Pro-oestrus & 11 & $\begin{array}{l}\text { Prolactin (1 to } 11) \\
\text { LH (8 to } 11)\end{array}$ & $32 \pm 2 \cdot 1$ & $219 \pm 27$ & Leucocytes \\
\hline $\mathbf{E}$ & Metoestrus & 11 & None (1 to 11$)$ & $40 \pm 2 \cdot 2$ & $113 \pm 5$ & Leucocytes \\
\hline $\mathbf{F}$ & Metoestrus & 11 & $\begin{array}{l}\text { None ( } 1 \text { to } 7) \\
\mathbf{L H}(8 \text { to } 11)\end{array}$ & $42 \pm 2 \cdot 7$ & $252 \pm 10$ & $\begin{array}{l}\text { Cornified } \\
\text { epithelial cells }\end{array}$ \\
\hline G & Metoestrus & 8 & Prolactin (1 to 11 ) & $38 \pm 2 \cdot 2$ & $167 \pm 25$ & Leucocytes \\
\hline $\mathbf{H}$ & Metoestrus & 12 & $\begin{array}{l}\text { Prolactin (1 to } 11) \\
\text { LH }(8 \text { to } 11)\end{array}$ & $48 \pm 1 \cdot 9$ & $184 \pm 12$ & Leucocytes \\
\hline
\end{tabular}

Uterine weights: A versus B, A versus D, B versus $\mathrm{C}, \mathrm{C}$ versus $\mathrm{D}, \mathrm{E}$ versus $\mathrm{F}(\boldsymbol{P}<0 \cdot 01)$. E versus $H, F$ versus $G, F$ versus $H(P<0.05)$.

Ovarian weights: A,B,C,D, versus E,F,G,H; A versus $C$; B versus $C$; $G$ versus $H$; $C$ versus $G$; D versus $\mathrm{H}(P<0.01)$.

A versus $D ; B$ versus $D ; E$ versus $H ; F$ versus $H(P<0.05)$.

* NIH-LH-B4 $50 \mu \mathrm{g}$ in $0.2 \mathrm{ml}$ sesame oil $+5 \%$ beeswax once daily, subcutaneously.

† NIH-P-s7 2.5 i.u. $(100 \mu \mathrm{g})$ in $0.2 \mathrm{ml}$ saline twice daily, subcutaneously.

$\ddagger$ Mean \pm S.E.

\section{DISGUSSION}

The foregoing experiments re-affirm our previous observations that rats hypophysectomized at any stage of the oestrous cycle secrete oestrogen in response to luteinizing hormone. These experiments confirm that if similar rats are provided with a pituitary graft or exogenous prolactin immediately after hypophysectomy and $\mathbf{L H}$ is subsequently administered, their vaginal smears contain leucocytes but no cornified epithelial cells. Histological preparations showed a mucified vaginal epithelium in rats treated with prolactin and LH following hypophysectomy during pro-oestrus which corresponds to the observed presence of leucocytes in the vaginal smears. 

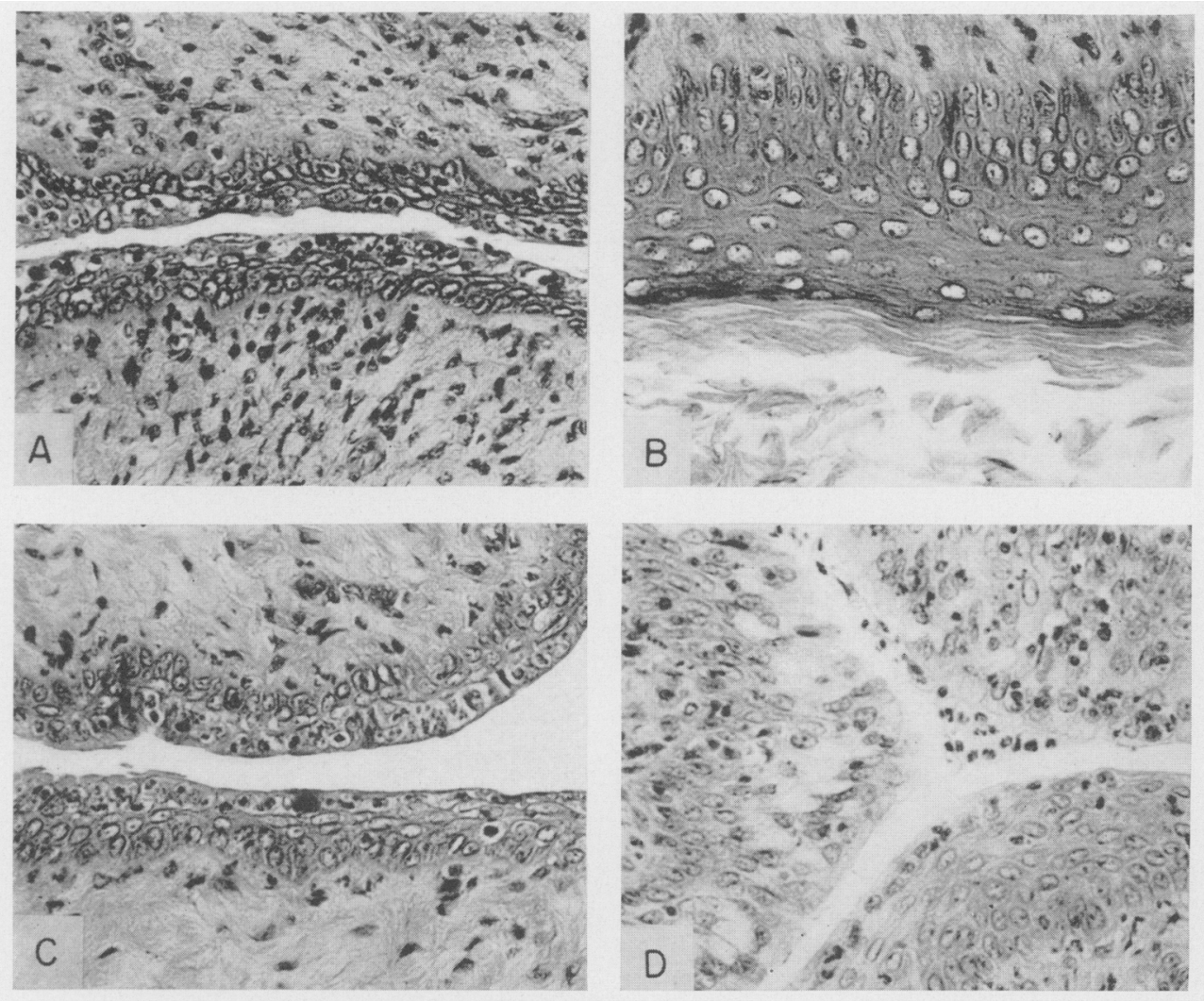

A. Vagina of rat hypophysectomizcd during pro-oestrus and killed 12 days later. Photomicrograph shows unstimulated epithclium. $\times 738$.

B. Vagina of rat hypophysectomized during pro-ocstrus and rested Days 1 to 7 . Rat treated with $50 \mu \mathrm{g} \mathrm{LH}$ (NIH-LH-B 4 ) in $0.2 \mathrm{ml}$ sesame oil plus $5 \%$ bceswax Days $8,9,10$ and 11 and killed on Day 12. Photomicrograph shows stratified and cornified epithelium. $\times 738$.

C. Vagina of rat hypophysectomized during pro-oestrus. Prolactin treatment began immediately (NLH-P-s $7,2.5$ i.u. in $0.2 \mathrm{ml}$ saline twice daily) and continued through Day 11. Rat killed on Day 12. Photomicrograph shows unstimulated epithelium. $\times 738$.

1). Vagina of rat hypophysectomized during pro-oestrus and treated with prolactin (NIH-P-s7, 2.5 i.u. in $0.2 \mathrm{ml}$ saline twice daily) through Day 11 and LH (NIH-LH-B4, 50 $\mu \mathrm{g}$ in $0.2 \mathrm{ml}$ sesame oil plus $5 \%$ beeswax, daily) on Days $8,9,10$ and 11 . Rat killed on Day 12 . Photomicrograph shows stratified and mucified epithclium. $\times 738$. 


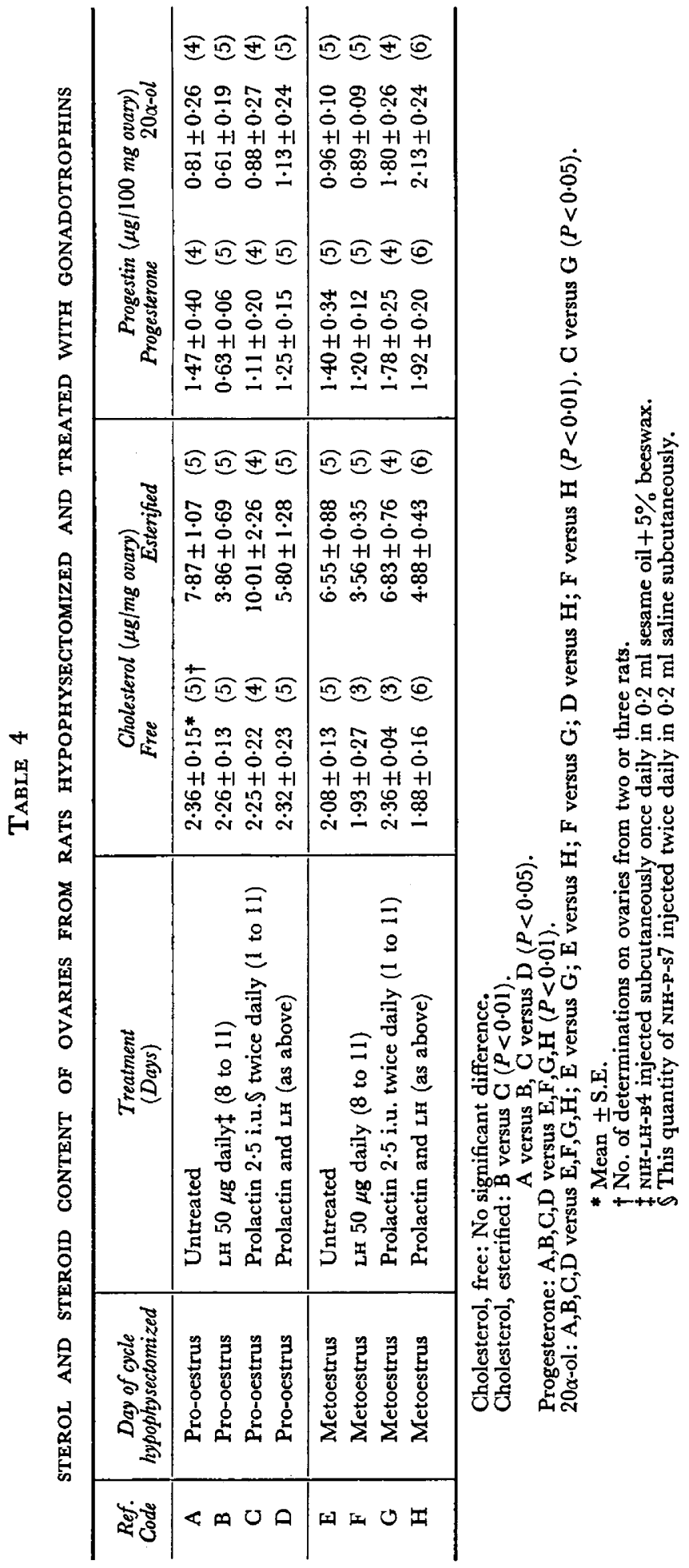


Measurements of the steroids contained in the ovaries of these rats shed little light on whether progesterone secretion is maintained by prolactin or varies due to LH treatment. However, the biological evidence strongly suggests that continued progesterone secretion is independent of the day of the cycle on which the animals were hypophysectomized. In the absence of prolactin, LH reduced the progesterone content only in animals operated on during prooestrus.

The possibility existed that the luteolytic influence of prolactin so reduced the amount of luteal tissue that oestrogen secretion evoked by LH was diminished. In this case the vaginal response would reflect insufficient oestrogen for cornification rather than a progesterone-oestrogen effect. From other unpublished data, cornified epithelial cells appeared in the vaginal smears of animals hypophysectomized in pro-oestrus and treated with prolactin for 11 days and then with $\mathbf{L H}$ in sesame oil and $5 \%$ beeswax daily for 4 additional days. This disallows the idea of an oestrogen lack due to reduced quantities of luteal tissues. The ovarian weights of these animals compared to rats which did not receive prolactin were statistically different $(P<0.01)$ apparently due to the reduction of luteal tissue by the luteolytic action of the administered prolactin (Malven \& Sawyer, 1966). These results demonstrated the luteolytic and luteotrophic influence of prolactin on the ovary in rats hypophysectomized during pro-oestrus. Those CL unable to secrete progesterone are lysed by prolactin. This is shown by the loss in ovarian weight. Corpora lutea capable of progesterone secretion persist, under the luteotrophic action of prolactin, and are macroscopically visible.

The amount of progesterone in ovarian vein blood of rats increases in response to administered LH during pro-oestrus (Yoshinaga, Grieves \& Short, 1967) and progestins increase in the ovary between 09.00 and 15.00 hours on the day of pro-oestrus (Lindner \& Zmigrod, 1967) which includes the suspected time of $\mathbf{L H}$ release. The level of $\Delta 5-3 \beta$-ol-steroid dehydrogenase necessary for the conversion of pregnenolone to progesterone in the ovaries of the rat is of the same magnitude during pro-oestrus as on the 5th day of pregnancy (Baldratti, Acerbi, Arcari, Ragazzi \& Suchowsky, 1967). From these observations, it is apparent that the ovary has the capacity to secrete progesterone during pro-oestrus and the amount can be increased by LH. In the normal animal, the quantity secreted before the LH surge is not great as indicated by the observation that the vaginal epithelium becomes cornified. In addition, rats bearing pituitary autografts (when the operation has been carried out in pro-oestrus) have insufficient quantities of progesterone to form deciduomata in response to uterine trauma or to block vaginal cornification in response to large doses of oestrogen. It has been demonstrated that $\mu$ g quantities of progesterone do not inhibit vaginal oestrus yet cause sufficient cervical relaxation to allow drainage of oestrogen-induced uterine fluid (Armstrong, 1966).

Our progesterone data from the rats with pituitary autografts compared to that of hypophysectomized, prolactin-treated animals suggest that the former preparation is better supported by the explant. This may be due to greater amounts of prolactin alone because evidence is available to support the idea of heightened progesterone secretion in rats with pituitary grafts. However, it is 
well-established that other trophic hormones are secreted in low quantities (Hertz, 1960) and this may contribute to the greater progesterone content observed. The source of progesterone in pro-oestrus is partially, if not entirely, dependent upon the presence of CL. Administration of testosterone to neonatal rats causes constant oestrus after puberty. The ovaries of these animals lack CL and the secretion of progesterone is low (Fajer \& Barraclough, 1966). A progesterone source appears necessary for ovulation as Everett $(1944,1948)$ has demonstrated that progesterone administration induces ovulation in rats experiencing constant oestrus induced by continuous illumination. These rats do not normally ovulate and lack CL.

Correlated with this, a progesterone surge before ovulation has been demonstrated in the rhesus monkey (Neill, Johansson, Datta \& Knobil, 1967) which complements the data on the rat (Eto, Masuda, Suzuki \& Hosi, 1962). This surge, a physiological event, may facilitate ovulation (Everett, 1944, 1948), cause relaxation of the cervix to allow flushing of the uterine lumen (Armstrong, 1966) and aid oestrogen for induction of sexual receptivity (Boling \& Blandau, 1939), each being part of the normal oestrous cycle.

The depletion of esterified cholesterol from ovaries of intact rats in response to injected LH has been reported (Herbst, 1967). The ability of LH to deplete esterified cholesterol in hypophysectomized rats appears to be independent of progesterone secretion and probably reflects the mobilization of cholesterol for the synthesis of oestrogen.

The ovarian weights of animals hypophysectomized during pro-oestrus and treated with prolactin or given pituitary grafts were lower than in comparable hypophysectomized controls. The difference is due to the lytic action of prolactin on non-functional corpora lutea. The weight difference was not evident in animals operated on during metoestrus. This preparation had greater numbers of newly-formed CL which were supported, rather than lysed, by prolactin.

The changes in uterine weights indicate the capacity of the ovaries to secrete steroids. Luteinizing hormone, given alone, increased uterine weights and induced fluid distension, indicating oestrogen secretion; given in addition to prolactin, the uterine weights were not as great as when LH was given alone but they were much above those of untreated controls. The smaller uteri and the absence of lumen fluid indicates that progesterone secretion was maintained.

The ovaries of rats hypophysectomized during pro-oestrus and maintained with either exogenous or endogenous prolactin are capable of secreting progesterone. The quantity is not equivalent to that secreted by the ovaries of animals operated on during metoestrus since the decidual response is not evoked, test-doses of oestradiol are not blocked and the progestin content of the ovaries is lower. However, the quantity of progesterone secreted together with the oestrogen secreted in response to $\mathbf{L H}$ is sufficient to induce development of the stratified and mucified vaginal epithelium.

\section{ACKNOWLEDGMENTS}

This investigation was supported by USPHS Grant AM00292. Luteinizing hormone (NIH-LH-B3 and B4) and prolactin (NIH-P-s7) were supplied by the 
Endocrine Study Section, National Institutes of Health, Bethesda, Maryland. The author wishes to express his gratitude for the consideration shown by Dr R. O. Greep, Dr D. T. Armstrong, Dr T. M. Jackanicz and Dr J. S. M. Hutchinson.

\section{REFERENCES}

Armstrong, D. T. (1966) Hormonal control of uterine fluid retention. Proc. 48th Meeting of the Endocrine Society, p. 67.

Armstrong, D. T., O'Brien, J. \& Greep, R. O. (1964) Effects of luteinizing hormone on progestin biosynthesis in the luteinized rat ovary. Endocrinology, 75, 488.

Baldratti, G., Acerbi, A., Arcari, G., Ragazzi, P. \& Suchowsky, G. K. (1967) Enzymatic activity of the ovary in relation to its ascorbic acid content and hypophyseal gonadotropins in the rat. Eur. 7. Steroids, 2, 33.

Boling, J. L. \& BlandaU, R. J. (1939) The estrogen-progesterone induction of mating responses in the spayed female rat. Endocrinology, 25, 359.

Eto, T., Masuda, M., Suzuki, Y. \& Hosi, T. (1962) Progesterone and pregn-4-ene-20 $\alpha$-ol-3-one in rat ovarian venous blood at different stages in reproductive cycle. Fap. F. Anim. Reprod. 8, 34.

EveretT, J. W. (1944) Evidence in the normal albino rat that progesterone facilitates ovulation and corpus luteum formation. Endocrinology, 34, 136.

Everet, J. W. (1948) Progesterone and estrogen in the experimental control of ovulation time and other features of the estrous cycle in the rat. Endocrinology, 43, 389.

Fajer, A. B. \& Barraclough, C. A. (1966) Progestin secretion in pseudopregnant, pregnant and androgen-sterilized rats. Excerpta Med. Int. Cong. Ser. 111, 364.

Heap, R. B. (1964) A fluorescence assay of progesterone. F. Endocr. 30, 293.

Henning, H. D. \& Zander, J. (1962) Verwendung von Hubeners 20 $\beta$-hydroxy-steroid-dehydrogenase bei mikrochemischer Identifizierung und Trennung von Steroiden. Hoppe-Seyler's Z.physiol.Chem. 330,31 .

Herbst, A. L. (1967) Response of rat ovarian cholesterol to gonadotropins and anterior pituitary hormones. Endocrinology, 81, 54.

Hertz, R. (1960) Gonadotropin and adrenocorticotropin from rat pituitary homografts as manifested by host response to chorionic gonadotropin and amphenone. Endocrinology, 66, 842 .

LINDNER, H. R. \& ZMIGROD, A. (1967) Microdetermination of progestins in rat ovaries: progesterone and $20 \alpha$-hydroxy-pregn-4-en-3-one content during prooestrus, oestrus and pseudopregnancy. Acta endocr., Copenh. 56, 16.

Macdonald, G. J., Armstrong, D. T. \& Greep, R. O. (1966) Stimulation of estrogen secretion from normal rat corpora lutea by luteinizing hormone. Endocrinology, 79, 289.

Macdonald, G.J., Armstrong, D. T. \& Greep, R. O. (1967) Initiation of blastocyst implantation by luteinizing hormone. Endocrinology, 80, 172.

Malven, P. V. \& SAWYer, C. W. (1966) A luteolytic action of prolactin in hypophysectomized rats. Endocrinology, 79, 268.

Neill, J. D., Johansson, E. D. B., Datta, J. K. \& Knobil, E. (1967) Relationship between the plasma levels of luteinizing hormone and progesterone during the normal menstrual cycle. $\mathbf{F}$. clin. Endocr. Metab. 27, 1167.

YoshinagA, K., Grieves, S. A. \& Short, R. V. (1967) Steroidogenic effects of luteinizing hormone and prolactin on the rat ovary in vivo. 7 . Endocr. 38, 423. 